\title{
Museum specimens: science, conservation and morality
}

\author{
J. V. REMSEN, JR
}

Bekoff and Elzanowski (1997) (hereafter "BE") have criticized my paper on the continuing importance of collecting scientific specimens of birds, focusing primarily on a brief section concerning "moral objections" to scientific collecting. $\mathrm{BE}$ seem to state either that it is acceptable to kill birds as long as every effort is made to reduce suffering, or that it is never acceptable to kill birds because suffering is unavoidable, depending on which portion of their essay is regarded as paramount. If their message is the former, then I and other museum scientists concur completely, because we already do this (contrary to the implications of $\mathrm{BE}$ ). If their message is the latter, then we have an impasse, with two different sets of personal moral standards. Although virtually every sentence by BE can be criticized, I restrict my rebuttal to the "top 10" most-revealing statements.

1. Birds ... are highly sentient beings and Sentience provides a generally recognized and scientifically grounded rationale for legitimate moral concerns about individuals... To support these statements, BE cite 11 references, including four of their own, most of which represent the opinions of those concerned with the issue of animal welfare. This hardly qualifies as "generally recognized" and "scientifically grounded". In fact, BE conceal the fact that those concerned with this issue (even within the references selectively cited) are strongly divided with respect to how to measure pain versus suffering, stress versus distress, consciousness and sentience, and which animals show what degree of self-awareness. As one could easily predict with respect to the difficulty of knowing what goes on in the minds of animals, the confidence exuded by $\mathrm{BE}$ is unjustified. Thus, the cornerstone of their thesis has little basis.

Rather than grope for some objective dividing line between animals that should not be valued as individuals and those that should, such as sentient versus non-sentient, why not lobby for maximum respect possible for all living creatures, including unicellular organisms and plants? My personal, moral stance, admittedly extreme, is that all living organisms merit ethical treatment and that no life should be taken deliberately without justification. This might be more easily defensible than BE's stance that "higher" vertebrates merit special treatment because they are currently considered sentient, with the implication that non-sentient organisms merit no concern.

2. Although some collectors try to be humane, no humane standards are institutionally enforced for collecting...

Evidently, BE are unaware that most universities, including my own, have animal welfare committees, which typically include veterinarians, that must 
approve research involving handling or killing of animals. Or are BE suggesting creation of a "police force" of field personnel to monitor collecting activities of museum scientists, because they regard them as incapable of policing themselves. If $\mathrm{BE}$ volunteer to accompany me on collecting trips, they are more than welcome, particularly if they are willing to euthanize the birds. Perhaps such first-hand experience would show them that we do care about the suffering of individual birds (even though we place higher value on the benefits to bird biology and conservation).

3. . . birds are commonly collected during the breeding season that causes starvation and death to individuals who depend on the collected individuals ...

Museum scientists, of course, are aware of this and are concerned about the suffering thus inflicted. Other than a ban on collecting during the breeding season, I see no resolution to this problem. If I thought that a self-imposed ban on collecting during the breeding season would be the impetus for a ban on all activities that inflict pain and suffering on dependent birds, then I would consider one. Banned activities would include use of all vehicles and aircraft with sufficient mass to kill birds, crop-harvesting in areas with bird nests, lumber operations, land-clearing activities, transport of petroleum and other hazardous materials, and maintenance of road and utility rights-of-way that would involve disturbing or destroying nesting habitat. Also necessary during the breeding season would be removal of all reflecting glass windows and confinement indoors of all pet cats. Perhaps BE believe that proposing such a ban would improve the image of scientists with the general public.

4. ... we oppose Remsen's hierarchy of values, with science and conservation placed so far above morality (and law) that any moral (and legal) objections that may interfere with the pursuit of these supreme goals should be discarded.

Such hyperbole characterizes much of BE's prose. Level-headed readers will recognize that just because my moral standards place the benefit of the data gained from the lives of a few individual birds above the cost in suffering to those birds, I do not suggest that morality has no place in decision making. Also, from their statement one might conclude that I wrote that there should be no legal restrictions on scientific collecting. On the contrary, I wrote that regulations should be designed for "maintaining control and monitoring scientific collecting." BE seem confused over the difference between proposed modifications to current legal procedures and the existence of the laws themselves.

5. The suppression of individual interests in the name of supraindividual values is as old as human civilization and has culminated in many devastating outbreaks of oppression and aggression.

I am not certain whether BE imply that scientific collecting represents creeping fascism or communism. Nevertheless, BE neglect to point out that suppression of individual interests in the name of supraindividual values, such as conservation, is one of the major obstacles to those who would devastate the planet's resources for individual gain. Conservation would not exist without it. Furthermore, the taxation of individuals "in the name of supraindividual values" makes possible the jobs and careers of BE. As for setting an example, BE deflect public concern for animals away from the global conservation crisis. BE attempt 
to provide academic legitimacy to the animal rights movement that defends the rights of individual feral pigs over the endangered Hawaiian ecosystem, the rights of individual feral burros over fragile island and desert ecosystems, and the rights of individual feral cats over threatened populations of native birds. Is this the price of sentience?

6. The way ornithologists treat birds sets an example for everybody else and frequently translates into laws via testimonies to legislative bodies.

$B E$ provide no documentation for this. I only wish that our way of treating birds did indeed translate directly into policy, because then the law would focus on the importance of habitats and the bird populations they support, rather than individual birds, as the supreme concern. Perhaps then it would become at least as difficult, legally, to destroy bird habitat as it is individual birds. Ironically, bird habitat owned privately and publicly can be converted to concrete with no legal barriers, whereas killing individual birds is strongly regulated.

7 ... he does not make special provisions for killing such long-lived birds ...

Actually, on p. 167 of my article (Remsen 1995), I did this by recommending that permit regulations stipulate smaller allowances for larger (longer-lived) birds.

8. Because too many ornithologists ignore avian sentience and its implications, today's ornithology conveys a distorted, impoverished picture of birds and deprives the public from the benefits of informed interactions with fellow sentient beings, benefits that some ornithologists come to appreciate (Skutch, 1996),

I can only imagine the deafening outbursts of laughter that such an absurd statement would bring from my fellow ornithologists, who have always been in the forefront of studies of animal behaviour and who are leaders in engaging the public in its appreciation. As for proposing Skutch as a model, perhaps BE are not aware that, among his many idiosyncratic beliefs (such as believing that birds sing because they like to listen to themselves), Skutch regards all snakes as "evil" and kills them on-sight. Or is that acceptable to BE because snakes are not (yet?) considered "sentient".

9. New humane principles and techniques can be tested and implemented only by practitioners in a field, which is why the possibility of humane refinements and alternatives cannot be realistically assessed as long as collecting continues to be done with a disregard for the interests of individual birds that characterizes Remsen's advocacy. This preposterous claim purports that somehow no alternatives can be sought while collecting continues, without providing a hint of why or how such an "either/or" fantasy could possibly be true (much less describe any alternatives). Nothing but their own lack of interest prevents BE from field-testing pain-minimizing techniques. Museum ornithologists welcome any advances in minimizing pain to individual birds.

10. Those who harm sentient beings must be held accountable for and justify their behaviour in ethical, not in technical (scientific) terms.

$\mathrm{BE}$ evidently do not care that the consumptive behaviours of all humans harm other sentient beings. Our use and consumption of agricultural products, petroleum products, chemicals, lumber, minerals, etc., inflicts suffering and distress on innumerable living organisms, including sentient ones, to whom it makes no difference whether or not the harm was intentional. Yet BE direct their energies against some of the only sources of harm that produce information that 
can be used to help other individuals of the animal species involved. We should all be working together to prevent the collapse of natural systems on the planet, while treating all individual animals with respect.

$B E$ have presented their view of morals and science. Now it's my turn. My moral view of responsible biological science is that it should benefit conservation, regardless of whether the organisms involved are sentient. In contrast to $\mathrm{BE}$, however, I would not force my morals on others, and I recognize a diversity of responsible moral stances. Because $\mathrm{BE}$ imply that any research, my own included, that inflicts pain and suffering on animals is immoral, they cannot object to a brief look at the morality of their own research. I can find no evidence that $\mathrm{BE}$ are concerned with conservation of populations or habitats, the primary theme of journals such as Bird Conservation International, so BE's research falls far short of my moral standards. Prior to his current preoccupation with criticizing other scientists for their lower moral standards, Bekoff's primary research focused on behaviour of the coyote Canis latrans, a species that, in contrast to many species of Canidae that are of concern to conservationists, thrives and spreads in human-disturbed habitats despite widespread persecution. Elzanowski's career $\backslash$ as an avian palaeontologist depends on availability of museum specimens of living species (collected by the scientists whose morals he criticizes) to make valid comparisons with fossils. In neither case have I been able to find any published evidence of concern for welfare of animal populations or habitats, only for the welfare of the immeasurably small fraction of individual "higher" vertebrates handled by scientists who study their biology. History may therefore view $\mathrm{BE}$ as lounging on the sidelines of the biodiversity crisis while indulging in self-righteous sermons concerning their own perceived moral superiority.

\section{References}

Bekoff, M. and A. Elzanowski (1997) Collecting birds: the importance of moral debate. Bird Conserv. Int.: 7: 357-361.

Remsen, J. V. (1995). The importance of continued collecting of bird specimens to ornithology and bird conservation. Bird Conserv. Int. 5: 145-180.

Skutch, A. F. (1996) The minds of birds. College Station: Rexas A \& M University Press.

J. V. REMSEN, JR

Museum of Natural Science, Louisiana State University, Baton Rouge, Louisiana 70803, U.S.A. 